was removed. Ten days after the operation, progesterone in doses of $0.1 \mathrm{mgm}$. and $1.0 \mathrm{mgm}$. was injected into normal animals and into the two types of hypophysectomized animals. Twenty hours after injection, readings were taken $(a)$ of the percentage positive response and $(b)$ of the extent of ovulation in positive animals. The latter was placed on a quantitative basis by assigning arbitrary symbols to the degree of ovulation: 1 or 2 according to the number of eggs in the oviduct; 3 or 4 according to the number in the pars uteri; and 5 or 6 according to the number of eggs extruded from the cloaca into the water in the container. The total score of all positive animals divided by the number of positive animals gives a figure which has been called the ovulation index. When less than 10 per cent of animals ovulate, not much significance can be attached to the index. The maximum ovulation index is 6 .

Immature normal animals (15-20 gm.) were also injected with progesterone. The average weight of the mature animals was $39 \mathrm{gm}$.

\begin{tabular}{|c|c|c|c|c|}
\hline \multirow{2}{*}{$\begin{array}{l}\text { Type of } \\
\text { animal }\end{array}$} & \multicolumn{2}{|c|}{$0.1 \mathrm{mgm}$. Progesterone } & \multicolumn{2}{|c|}{$1.0 \mathrm{mgm}$. Progesterone } \\
\hline & $\begin{array}{c}\text { Percentage } \\
\text { response }\end{array}$ & $\begin{array}{c}\text { Ovulation } \\
\text { index }\end{array}$ & $\begin{array}{l}\text { Percentage } \\
\text { response }\end{array}$ & $\begin{array}{c}\text { Ovulation } \\
\text { index }\end{array}$ \\
\hline Normal & 35 & $2 \cdot 3$ & 100 & $4 \cdot 5$ \\
\hline $\begin{array}{l}\text { Anterior lobe } \\
\text { removed }\end{array}$ & 16 & $1 \cdot 2$ & 67 & $2 \cdot 8$ \\
\hline $\begin{array}{l}\text { Both lobes } \\
\text { removed }\end{array}$ & $6 \cdot 5$ & $(1 \cdot 5)$ & 30 & $3 \cdot 1$ \\
\hline $\begin{array}{c}\text { Immature } \\
\text { normal }\end{array}$ & 9.5 & $(2 \cdot 0)$ & 43 & $3 \cdot 0$ \\
\hline
\end{tabular}

The results show that ovulation occurs in the absence of the pituitary, but that both the anterior and pos. terior lobes must be present before the maximum percentage of positive response can be obtained. On the other hand, an increase in the extent of ovulation is dependent upon some factor in the anterior lobe alone. Immature animals give a higher percentage response than completely hypophysectomized frogs but the same ovulation index.

Normal and completely hypophysectomized animals were injected with pregnancy urine extract. The dose chosen was that which just gave 100 per cent response when injected into normal animals. The hypophysectomized frogs gave 100 per cent response and an ovulation index of $5 \cdot 5$. The index in normal frogs was $5 \cdot 0$.

There was no significant difference in percentage response and ovulation index between completely hypophysectomized animals injected with progesterone alone and the same type of animal injected with progesterone and Parke, Davis pituitrin.

The ovulating effect of progesterone is strikingly demonstrated by its action on the excised ovaries of normal and hypophysectomized animals. The ovary is excised and placed in a glass dish containing Ringer's solution. The addition of $1 \mathrm{mgm}$. progesterone causes extrusion of numerous ova within 8-10 hours at a temperature of $21^{\circ} \mathrm{C}$.

Coupling, ovulation and fertilization of eggs were induced by injecting males with anterior pituitary extract and females with progesterone. Ovulation and oviposition occur after injection of so small a dose as $0.05 \mathrm{mgm}$. progesterone.

Since the completion of these experiments, Shapiro ${ }^{1}$, at the National Institute for Medical Research, Hampstead, has confirmed the findings for progesterone induced ovulation in Xenopus and has obtained the same result with the following steroids : methyltestosterone, testostcrone, allo-pregnanedione, androstenedione, trans-dehydroandrosterone, cisandrostanediol, androsterone, Reichstein's adrenal substance J, "Eucortone" adrenal cortical extract. H. ZWARENSTEIN,

\author{
Department of Physiology, \\ University, \\ Cape Town. \\ Dec. 9. \\ IShapiro, H. A., Chem, and Ind., 55, 1031 (1936).
}

\section{Segmental Interchange Lines in Pisum sativum}

IN collaboration with Miss Pellew, crosses between a number of lines of spontaneous or natural origin, showing interchange of segments between nonhomologous chromosomes in Pisum sativum, have been studied at the John Innes Horticultural Institution, Merton, and at the Botanical Department, University of Manchester.

As a result of the analysis of the chromosome associations at meiosis in these crosses (seven pairs or an association of four-not a ring-results when the same two chromosomes are concerned in the two interchanges, an association of six when one chromosome is common to both interchanges, and two rings of four when entirely different chromosomes are affected), seven types differing in chromosome structure and therefore called 'structural types' have been distinguished, and their interrelationships determined. The chromosomes taking part in these interchanges are as follows, where arbitrary numbers are given to the seven haploid chromosomes of the normal or standard type :

Struetural type 1. The normal or standard type.

Structural type 2. Chromosomes $1,2,3,4,5,6,7$.

Structural type 2. Hammarlund's $\not{K}$-line. 2 interchanged.

Structural type 3. The rhibet interchanged line. Chromosomes 1 and 3 interchanged.
Structural type 4 . Fixtra rapid.

Structural type 4 . Fixtra rapid.

Struetural type 5 . An interchanged type from Miss de Winton's material.

Chromosomes 4 and 5 interchanged.

Structural type 6. Wing's line.

Chromosomes 1 and 4 interchanged.

Structural type 7. The doubly-interchanged type from stmetural type $2 \times$ structural type 3 .

Chromosome 1 interchanged with 2 and 3 .

Structural type 7 when crosised with structural type 6 gives, as expected, an association of eight chromosomes at meiosis, the highest association yet reported in Pisum.

Nilsson ${ }^{1}$ studied the relationships between structural type 4 and three other types which cannot be classified in relation to those recorded in the present communication until the necessary tests have been made.

Botanical Department,

E. Sansome.

University,

Manchester.

Dec. 16.

${ }^{1}$ Nilsson, E., Hereditas, 21 (1935-36).

\section{Linkage in Structural Hybrids in Pisum sativum}

THE genetical analysis of some of the interchanged lines in Pisum sativum, reported on by Mrs. Sansome above, has given evidence on the distribution of the genes in the normal structural type. In plants of normal structure the genes $R(R / r=$ round/wrinkled cotyledons) and $A$ ( $A / a=$ coloured/white flowers $)$ have been 